\title{
Effect of Non-Genetic Factors on Somatic Cell Count in Sirohi Goats
}

\author{
Mahendra Pal Poonia ${ }^{1 *}$, Sanjita Sharma ${ }^{1}$, Navav Singh ${ }^{1}$, Amit Sharma $^{2}$, \\ Brijesh Nanda ${ }^{1}$ and Yashahshree Gautam ${ }^{1}$
}

\author{
${ }^{1}$ Department of Livestock Production Management, Post Graduate Institute of Veterinary \\ Education and Research, Jaipur-302031, India \\ ${ }^{2}$ Department of Animal Husbandry, Government Veterinary Hospital, Kohala, \\ Banswara- 327025, India \\ *Corresponding author
}

\begin{tabular}{|c|}
\hline Keywords \\
\hline $\begin{array}{l}\text { Somatic cell count, } \\
\text { Subclinical mastitis, } \\
\text { Parity, Stage of } \\
\text { lactation, Prolificacy }\end{array}$ \\
\hline Article Info \\
\hline $\begin{array}{l}\text { Accepted: } \\
26 \text { February } 2018 \\
\text { Available Online: } \\
10 \text { March } 2018\end{array}$ \\
\hline
\end{tabular}

\section{Introduction}

Goat milk production is a dynamic and growing industry that is fundamental to the well-being of millions of people worldwide and is an important part of the economy in many countries (Silanikove et al., 2010). In India there are about 135.17 million goats (26.4 percent of total livestock) producing
Goat milk has higher Somatic Cell Count (SCC) and the ability to correctly interpret somatic cell counts in goat depends on an understanding of the various factors which may affect the number of somatic cells. The present study was carried out to determine the effect of non-genetic factors on Sub Clinical Mastitis (SCM) and to investigate the relationships between these factors with Somatic cell count (SCC) in 105 Sirohi goats raised at Sheep breeding farm Fatehpur, Sikar in Rajasthan, India. Milk samples were collected from udder halves of lactating goats and examined by somatic cell count to check the status of subclinical mastitis. Data were collected from the record register maintained at farm and data evaluated by Parity, Stage of Lactation and Prolificacy by the SPSS packet program. On analysis of variance result revealed that the parity had highly significant $(\mathrm{P}<0.01)$ effect on SCC. Higher incidence of SCM was in later parities in comparison to primiparous animals. Stage of lactation had also significant effect $(\mathrm{P}<0.05)$ on the $\log _{10} \mathrm{SCC}$ and indicated that composite SCC increased with the advancement of lactation while non-significant effect on $\log _{10} \mathrm{SCC}$ has been found with prolificacy. So it can be concluded from the present study that the non-genetic factors like parity, stage of lactation and prolificacy have a significant effect on Milk SCC. Thus, goat farmers are advised to spend more time on their herds and given extra care to their animals in later parity and last stage of lactation to prevent the infection of sub clinical mastitis. 
hygiene and mastitis control (Sharma et al., 2016a). Milk secretion in goat is an apocrine process which results in presence of many cytoplasmaic particles. This type of secretion is characterized by the detachment of the apical part of the epithelial cells from their base and release into the alveolar lumen at the end of the secretory phase (Makovicky et al., 2012) resulting in higher SCC than cow milk and sheep milk. According to National Mastitis council, to differentiate between healthy and infected udder secretion the limit of SCC has been decided as 10,00,000 cells/ml. (Hinckley and Williams., 1981).

Somatic cells are present in healthy mammary glands but due to any kind of mammary inflammation there is an increase influx of cells and it is important to understand different non-infectious factors which affect Somatic Cell Count. In present study observations collected and analyzed for effect of Parity, stage of lactation and prolificacy on Somatic Cell Count. A number of studies have been done to investigate the relation of these nongenetic factors i.e. parity, stage of lactation, prolificacy etc. with occurrence of intramammary infection under different climatic conditions but information regarding Indigenous Goat breeds are scanty.

So the present study was conducted to determine the effect of parity, stage of lactation and prolificacy on milk Somatic Cell Count in Sirohi goats.

\section{Materials and Methods}

\section{Location}

The study was conducted at Sheep breeding farm Fatehpur, Sikar. Goat paddock located in Fatehpur city of Rajasthan. The altitude of Fatehpur city is 324 meter above mean sea level, latitude and longitude position being $27.98^{\circ} \mathrm{N}$ and $74.95^{\circ} \mathrm{E}$, respectively.

\section{Animal}

Out of total number of goats in milk total, 105 healthy lactating Sirohi goats with no evidence of clinical mastitis were selected and the collection and analysis of milk samples were performed on the same day.

\section{Collection of samples and diagnosis of Intra-mammary Infection}

Representative milk samples were collected from udder halves of lactating goats. For this purpose, udder halves were designated as Left teat (LT) and Right teat (RT). About $30 \mathrm{ml}$ of milk was collected aseptically in the clean sampling bottles after discarding the first 2-3 streaks of fore milk. The collected samples were brought to the laboratory immediately for further analysis. Within $6 \mathrm{~h}$ of collection, the milk samples were spread on 2 microscope slide areas, which were $10 \times 10 \mathrm{~mm}^{2}$ in size subsequently. The slides were fixed with pouring of ethyl alcohol for 2 minutes and the prepared smears were stained with the modified Newman's Lampert stain, by keeping the prepared slide in the staining solution for 1 to 2 minutes. The smears were gently washed in tap water and dried. The dried stained smears were examined under the oil immersion lens of the microscope. Thirty different fields per smear were observed, and the average number of somatic cells per field was calculated. The average number of cells per field was then multiplied by the microscopic factor of the microscope, i.e. 318471 to obtain the number of somatic cells per ml of the milk. Due to SCC not displaying a normal distribution, data of SCC were log transformed to base 10 .

\section{Data collection}

Data were collected from the record register maintained at farm and data of SCC from all animals were classified according to parity, 
stage of lactation and prolificacy. All these parameters were taken into consideration as for the factors influencing the occurrence of SCM and SCC.

Parity: All animals were classified under the different parities (viz., $1^{\text {st }}, 2^{\text {nd }}, 3^{\text {rd }}$ and above) according to their lactation number.

Stage of lactation: The whole lactation was partitioned early stage of lactation ( 0 to 2 month), mid stage of lactation (2 - 4 month) and late stage of lactation (above 4 month). Prolificacy: Goats were classified according to number of kids born in last parturition (viz., single and double)

\section{Statistical analysis}

Obtained SCC values were transformed to $\log _{10}$ SCC for normality and homogeneity of variance. In the study, parity, stage of lactation and prolificacy were evaluated as independent variables. The data were examined by Analysis of Variance (ANOVA) and means were compared by Duncan's multiple range test. The model was as follows:

$\mathrm{y}_{\mathrm{ijklm}}=\mu+\mathrm{a}_{\mathrm{i}}+\mathrm{b}_{\mathrm{j}}+\mathrm{c}_{\mathrm{k}}+\mathrm{d}_{\mathrm{ijklm}}$

Where:

$\mathrm{y}_{\mathrm{ijklm}}=$ Observation value for SCC

$\mu=$ Population mean

$\mathrm{a}_{\mathrm{i}}=$ Effect of Parity $(\mathrm{I}=1,2,3$ and above $)$

$b_{j}=$ Effect of Stage of lactation $(j=1,2,3)$

$c_{\mathrm{k}}=$ Effect of prolificacy $(\mathrm{k}=1,2)$

$\mathrm{d}_{\mathrm{ijklm}}=$ The Random residual effect

All statistical analysis was performed using SPSS software statistical package (16.0).

\section{Results and Discussion}

Results of SCC in milk samples of Sirohi goats are presented in Table 1 . The arithmetic mean \pm SE of SCC (absolute and logarithmic) of pooled milk sample were 8,22,009 \pm 23415 cells/ml of milk and $5.894 \pm 0.141$ respectively. Range of SCC varied from $2,91,132$ cells/ml to $13,74,733$ cells/ml of milk samples collected from farm (Table 1).

Udder half-wise means \pm SE of $\log _{10} \mathrm{SCC}$ has been presented in the Table 2 where highest values found in right udder half i.e., $5.899 \pm 0.045$. Higher incidence of SCC in right udder halves in present study is due to the resting behavior of the animals as the animals resting more in right lateral recumbence keeping the rumen upside (left side). This causes the positioning of right udder halves close to the ground which increases the chances of infection.

\section{Effect of parity on milk SCC}

After statically analysis results of the present study revealed that incidence of SCM increased with number of parity. The lowest incidence was observed in $1^{\text {st }}$ parity (20.00 per cent), gradually increased and highest in $>3^{\text {rd }}$ parity (57.14 per cent) in Sirohi goats.

Several workers reported similar findings that enhancing milk production level and a rise in SCC with increasing parity in goats (Moroni et al., 2005; Leitner et al., 2008; Tancin, 2013; and Sharma et al., 2016b).

The analysis of variance showed that the effect of parity on $\log _{10} \mathrm{SCC}$ was highly significant $(\mathrm{P}<0.01)$ (Table 3$)$. Mean $\log _{10}$ SCC of Individual parity was compared by Duncan's Multiple Range Test. The results of post hoc test revealed that the mean $\log _{10} \mathrm{SCC}$ of $1^{\text {st }}, 2^{\text {nd }}$ and $3^{\text {rd }}$ parity was significantly $(\mathrm{P}<0.05)$ differ from each other (Table 4). 
Table.1 Incidence, Mean \pm SE values \& range of somatic cell counts

\begin{tabular}{|l|l|l|l|}
$\begin{array}{l}\text { Number of } \\
\text { observations }\end{array}$ & $\begin{array}{l}\text { Mean } \pm \text { SE } \\
(\text { cells/ } \mathrm{ml})\end{array}$ & $\begin{array}{l}\text { Mean } \pm \text { SE } \\
(\log 10 \mathrm{SCC})\end{array}$ & Range $(\mathrm{cells} / \mathrm{ml})$ \\
\hline $\mathbf{1 0 5}$ & $8,22,009 \pm 23415$ & $5.894 \pm 0.141$ & $2,91,132-13,74,733$ \\
\hline
\end{tabular}

$\mathrm{SE}=$ Standard error, $\mathrm{SCC}=$ Somatic cell count

Table.2 Udder half-wise Mean \pm SE values of $\log _{10} \mathrm{SCC}$

\begin{tabular}{|l|}
\hline Different Udder halves \\
\hline Overall mean \\
\hline Left udder half \\
\hline Right Udder half \\
\hline
\end{tabular}

\section{Number of \\ observations}

210

105

105
Mean \pm SE

$\log _{10} \mathrm{SCC}$

$5.893 \pm 0.021$

$5.889 \pm 0.044$

$5.899 \pm 0.045$

Table.3 Mean \pm SE of $\log _{10}$ SCC in different non genetic factors in Sirohi goats

\begin{tabular}{|c|c|c|}
\hline Traits & Number of observations & Mean \pm SE of $\log _{10} S C C$ \\
\hline Parity & 105 & $5.894 \pm 0.141$ \\
\hline I & 15 & $5.774 \pm 0.193^{\mathrm{a}}$ \\
\hline II & 69 & $5.895 \pm 0.119^{b}$ \\
\hline III and above & 21 & $5.972 \pm 0.109^{c}$ \\
\hline Stage of Lactation & 105 & $5.894 \pm 0.141$ \\
\hline Early stage (0 - 2 month) & 42 & $5.841 \pm 0.154^{\mathrm{a}}$ \\
\hline Mid stage (2-4 month) & 36 & $5.915 \pm 0.107^{b}$ \\
\hline Late stage (above 4month) & 27 & $5.946 \pm 0.137^{b}$ \\
\hline Prolificacy & 105 & $5.894 \pm 0.141$ \\
\hline Single & 76 & $5.885 \pm 0.135$ \\
\hline Double & 29 & $5.915 \pm 0.155$ \\
\hline
\end{tabular}

Mean showing different superscripts in lower case letters in respective categories in a column differ significantly $(\mathrm{p}<0.05), \mathrm{SE}=$ Standard error, $\mathrm{SCC}=$ Somatic cell count

Table.4 Analysis of variance showing the effect of non-genetic factors on SCC in Sirohi goats

\begin{tabular}{|l|c|c|c|c|}
\hline Source of variance & Degree of freedom & Sum Square & Mean Sum square & F - value \\
\hline Parity & 2 & 0.344 & 0.172 & $10.090^{* *}$ \\
\hline Error & 102 & 1.738 & 0.017 & \\
\hline Stage of lactation & 2 & 0.207 & 0.104 & $5.640 *$ \\
\hline Error & 102 & 1.875 & 0.018 & \\
\hline Prolificacy & 1 & 0.019 & 0.019 & 0.954 \\
\hline Error & 103 & 2.063 & 0.020 & \\
\hline
\end{tabular}

SCC $=$ Somatic cell count, $* *$ Highly Significant $(\mathrm{p}<0.01), *$ Significant $(\mathrm{p}<0.05)$ 
Similar significant association of parity with $\log _{10} \mathrm{SCC}$ were reported by Saanchez et al., (1991), Rota et al., (1993), Orman et al., (2010), Kralickova et al., (2012), Tancin (2013) and Sharma et al., (2016b) whereas Sharma et al., (2007) and Leinter et al., (2008) reported non-significant effect of parity on SCC.

High SCC in later parity in comparison to primiparous animals may be due to the fact that constant exposure of animals to the pathogens and loosening of sphincters, help the easy entry of organism through streak canal which is responsible for higher rate of infection in multiparous animals in comparison to younger counterparts.

Further, animal resistance to mastitis might also be lowered with advancement of parity or age. Yu et al., (2011) reported that with the increase of parity, the ratio of macrophages (MAC) and polymorphonuclears (PMN) tended to be increased and suggested that progressive increase of SCC when parity increased. Streak canal of the teats consists keratinized layer and accumulated cellular debris, which is wax like and having sebum like nature consisting of long chain fatty acids, which provides bacteriostatic effects (Mostert et al., 2001). The breakdown of such streak canal barrier with advancing lactation leads to increased frequency of infection with successive increase in parity. The incidence of SCM and SCC increased as the lactation progressed and it attained the highest proportion during the $3^{\text {rd }}$ and above parity.

\section{Effect of stage of lactation on milk SCC}

Results indicated that composite SCC increased with the advancement of lactation. The mean \pm SE values of $\log _{10}$ SCC have been $5.841 \pm 0.154, \quad 5.915 \pm 0.107$ and $5.946 \pm 0.137$ in early, mid and late stages of lactation, respectively
The analysis of variance revealed that the stage of lactation had significant effect $(\mathrm{P}<0.05)$ on the $\log _{10}$ SCC. The Duncun multiple range tests revealed that the difference between the mean $\log _{10} \mathrm{SCC}$ of mid and late stage of lactation were differ significantly from early stage of lactation but did not differ significantly from each other.

Various workers viz., Bufano et al., (1996), Kuchtik et al., (2006), Diana and Rotaru (2006), Orman et al., (2011) and Sharma et al., (2016b) found high SCC in late stage of lactation and also reported significant changes in SCC during different stages of lactation which support the results of present study. Bergonier et al., (2003) and Dankow et al., (2003), reported that SCC in uninfected goats is high at freshening, lowest from peak to mid-lactation and highest at drying off while Gomes et al., (2006), Houda et al., (2012) and De et al., (2011) reported non-significant changes in SCC during different stages of lactation.

Physiologically, dairy goats have SCC with an upward trend corresponding to the progression of the productive period (Poutrel et al., 1997).

This trend shows an inverse relationship with milk production (Rota et al., 1993). Thus, the cellular concentration of goat milk is so high that, according to Corrales et al., (1996), at the end of lactation it is impossible to distinguish between uninfected and healthy glands through SCC.

\section{Effect of prolificacy on milk SCC}

Data revealed that the mean $( \pm \mathrm{SE}) \log _{10} \mathrm{SCC}$ value in case of single and double prolificacy are $5.885 \pm 0.135$ and $5.915 \pm 0.155$ respectively. The analysis of variance revealed that the prolificacy has nonsignificant effect on $\log _{10}$ SCC (Table 4). 
Sanchez-Rodriguez et al., (2000) and Olechnowicz and Sobek (2008) supported the present findings and reported that the Prolificacy had no significant effect on somatic cell count.

It is concluded from the present study that the non-genetic factors i.e. parity, stage of lactation and prolificacy have some degree of association with prevalence of subclinical mastitis.

Therefore their inclusion in selection and breeding programme as indicator trait may help to improve udder health and milk quality in Sirohi goat.

\section{Acknowledgment}

We are grateful to Dean PGIVER, Jaipur (RAJUVAS) for providing facilities, continuous encouragement and support during the study.

\section{References}

Bergonier, Dominique, Renee de Cremoux, Rachel Rupp, Gilles Lagriffoul and Xavier Berthelot. (2003). Mastitis in dairy small Ruminants. Veterinary Research, 34:689-716.

Bufano, G., Dario, C., Laudadio, V. (1996). The characterisation of Leccese Sheep: variation of chemical composition and lactodynamographic parameters in milk as related to Somatic Cell Counts. Proceedings of the International symposium of Somatic Cells and milk of small Ruminants. pp 301-304.

Corrales, J.C., Contreras, A., Siera, D., Marco, J. (1996). Physiological threshold of Somatic Cell Count and California Mastitis Test for diagnosis of Caprine Subclinical Mastitis. Small Ruminant Research. 21(3):259-264.

Dankow, R., Pikul, J., Sokolinska, D cais., Wojtowski, J. (2003). Cytological quality of goat milk. Medycyna watery naryjna. 59(1) 77-80.

De, k., Mukherjee, J., Prasad, S. and Dang, A. K. (2011). Effect of parity and stage of lactation on milk SCC and DLC in native and crossbred cows. Indian Journal of Dairy Science, 64 (4): 326-328.

Diana, S. and Rotaru (2006). Somatic cells and milk health. Seria Medicina Veterinara. 63: 385-390.

Gomes V., Libera A.M.M.P.D., Paiva, M., Madureira K.M. and Araujo W.P. (2006). Effect of the stage of lactation on somatic cell counts in healthy goats. (Caprae hircus) breed in Brazil. Small Rumin Res. 64(1/2):30-34.

Houda, H,. Trujillo, A. J., Juan, B., Guamis, B., Eifeki, A. and Gargouri, A. (2012). Interrelationships between somatic cell counts, lactation stage and lactation number and their influence on plasmin activity and protein fraction distribution in dromedary (Camelus dromedaries) and cow milks. Small Ruminant Research, 105: 300-307.

Kralickova, S., Kuchtik J., Filipcik, R., Luzova T. and Sustova, K. (2012). Effect of chosen factoers on milk yield, Basic composition and Somatic Cell Count of organic milk of Brown short haired Goats. Acta Universitatis Agriculturae Et Silviculturae Mendelianae Brunensis. dx.doi.org/10.11118/actaun20/361010099

Kuchtik, J., Sustova, K., Urban, T. and Zapletal, D. (2006). Effect of the stage of lactation on milk composition, its properties and the quality of rennet curdling in east Friesian Ewes. Czech J.Anim.Sci. 53(2):55-63.

Leitner, G., Silanikove, N. and Merin, V. (2008). Estimate of milk and curd yield loss of sheep and goats with intramammary infection and its relation to somatic cell count. Small Rumin. Res., 74: 221-225.

Makovicky, P., Peter, M., Melinda, N., Kvetoslava, R., Jana, D. (2014). Genetic parameters for somatic cell count, LOGSCC and somatic cell score of 
Breeds, Improved Valachian, TSIGAI, LACUNE and their crosses. Acta Veterinaria Beograds. 4 (3): 386-396.

Moroni, P., Pisoni, G., Ruffo, G., Boettcher, P.J. (2005). Risk factors for intramammary infections and relationship with somatic-cell counts in Italian dairy goats. Prev Vet Med. 69(3-4): 163-73.

Mostert, B.E., Theron, H.E. and Kanfer, F.H.J. (2001). The effect of calving season and age at calving on production traits of South African dairy cattle. South African Journal of Animal Science, 31(3): 205214.

Olechnowicz, J., Sobekk Z. (2008). Factors of variation influencing production level, SCC and basic milk composition in dairy goats. Journal of Animal and Feed Sciences, 17:41-49.

Orman, A. Gunay, A, Balci, IF, Koyuncu, M., (2011). Monitoring of somatic cell count variations during lactation in primiparous and multiparous Turkish Saanen goats (Capra hircus). Turk. J. Vet. Animal Science. 35(3):169-175.

Poutrel, B. and Lerondelle, C. (1983). Cell content of goat milk: California Mastitis Test, Coulter counter and Fossomatic for predicting udder half infection. Journal of dairy Science, 66:2575-2579.

Rota A.M., Gonzalo C., Rodriguez P.L., Rojas A.I. and Tovar J.J. (1993). Effects of stage of lactation and Parity on somatic cell counts in milk of Verata goats and algebraic models of their lactation curves, Small Ruminant Research, 12 (2): 211219.
Saanchez, A., Contreras, A. and Corrales, J. C. (1991). Parity as a risk factor for caprine subclinical intramammary infection, Small Rumin. Res., 31: 197-201.

Sharma S.K., Tanwar R.K., Gahlot A.K., Monika Joshi (2007). Somatic cell counts in relation to caprine subclinical mastitis. Indian Journal of Veterinary Medicine. 27 (2): 149-150.

Sharma, A., Sharma, S., Singh, N., Pal, R.S. and Nanda, B. (2016b) Impact of udder and teat morphometry on udder health in Tharparkar cows under climatic condition of hot arid region of Thar desert. Trop.Anim.Health prod. 6(6):1001-1005.

Sharma, A., Sharma, S., Singh, N., Sharma, V. and Pal, R.S. (2016a) Effect of NonGenetic Factors on Somatic Cell Count in Tharparkar Cows under Hot Arid Region of Thar Desert Area. Journal of Animal Research. 48:1647-1652.

Silanikove, N., Leitner, G., Merin, U. (2010). Effects of glandular bacterial infection and stage of lactation on milk clotting parameters: comparison among cows, goats and sheep. International Dairy Journal.10: 946-958.

Tancin, V. 2013. Somatic cell counts in milk of dairy cows under practical conditions. Slovak J. Anim. Sci. 46 (1): 31-34.

Yu, A. B., Zhao, G. Q., Tian, S. Q. and Huo, Y. J., (2011). Relationship between parity and cellular composition of somatic cells in milk of Chinese Holstein cows. Journal of Animal and Veterinary Advances. 10 (16): 2067-2073.

\section{How to cite this article:}

Mahendra Pal Poonia, Sanjita Sharma, Navav Singh, Amit Sharma, Brijesh Nanda and Yashahshree Gautam. 2018. Effect of Non-Genetic Factors on Somatic Cell Count in Sirohi Goats. Int.J.Curr.Microbiol.App.Sci. 7(03): 3164-3170. doi: https://doi.org/10.20546/ijcmas.2018.703.365 